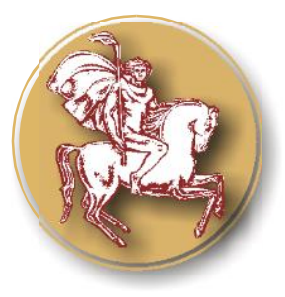

Original Contribution

\title{
SCREENING CAPSICUM GENOTYPES FOR INCREASED DROUGHT TOLERANCE BY IN VITRO POLLEN GERMINATION AND POLLEN TUBE LENGTH
}

\author{
Y. Arnaoudova*, B. Arnaoudov \\ Maritsa Vegetable Crops Research Institute, Plovdiv, Bulgaria
}

\begin{abstract}
Yield realizing in vegetable crops depends on several reproductive processes that include pollen fertility as well as pollen tubes germination and growth. The study was conducted as the pollen characteristics fertility and viability were used, as well as the productivity for evaluation of drought tolerance in four pepper genotypes Capsicum annuum L. From the conducted cytological analyses was found that decreasing the water standard with $50 \%$ exert negative influence over the male gametophyte and the pollen fertility decreases with up to $37.4 \%$ average. More sensitive to drought showed to be the plants from both cultivars Pazardzhishka kapia and Albena, in which lower productivity and lower restorable potential were found in comparison with those found in the mutant lines No.1936 and No.1917. Increased tolerance showed the male gametophyte of line No.1936. After a drought in it were found the highest values for pollen viability $-33.4 \%$ average pollen germination and $438.7 \mu \mathrm{m}$ pollen tubes length which was with proven mathematical difference compared with the rest of the genotypes. These results showed that pollen fertility analyses and pollen viability analyses in drought plants could be used for evaluation of the drought tolerance.
\end{abstract}

Key words: Drought tolerance, pollen fertility, fruit yield, pepper Capsicum annuum L.

\section{INTRODUCTION}

On a world scale, a water stress is accepted as an explicitly serious problem that inhibits plants productivity $(1,2)$. Bell pepper (Capsicum annuum L.) is one of the most important cultures in the world (3) and is one of the most pliable to water (4-6). The drought in the pepper production, impose great yield decreasing and quality of the sowing with significant economic losses up to $70 \%(6,7)$.

Various physiological criteria have been proposed by several authors in different crops however, there is limited information on the use of drought tolerance indices on important agronomic traits of pepper (8-12). Plant reproductive development is more sensitive to environmental stresses such as drought (13-16) compared to vegetative growth and male

\footnotetext{
*Correspondence to: Yanina Arnaudova, "Maritsa" Vegetable Crops Research Institute, Plovdiv 4003, 32 Brezovsko shousse str., yanina_arnaudova@abv.bg
}

Gametophyte development it is the most sensitive stage in the plant life cycle being easily affected by stressful environment (17, 18).

The aim of this study was to evaluate the drought resistance through analysis of the male gametophyte and the productivity in four pepper genotypes.

\section{MATERIALS AND METHODS}

The experiments were conducted in glasshouse Venlo type in the MVCRI, Plovdiv, Bulgaria with four pepper (Capsicum annuum L.) genotypes - two cultivars Pazardzhishka kapia and Albena and two mutants line No.1917; No.1936. The plants will be cultivated as a substrate culture without heating. The trial will be put by the block method in three repetitions as in each repetition there will be by 4 plants.

During the bud formation-blossoming period, the plants were exposed in two watering regimes: the first regime - Control $100 \%$ watering norm (the number of the watering 
will correspond to the perceived for that production technology) and the second regime - drought 50\% watering norm (the number of the watering will be reduced with 50\% towards the perceived for that production technology).

Pollen fertility was studied in five or more flowers from each plant in the different genotypes. Temporary preparations are made and they are colored with a mixture of $4 \%$ acetocarmine and glycerine in correlation 1:1. At least 100 pollen grains are enumerated from different visual fields. The percentage of the colored (fertile) and non-colored (sterile) pollen is defined.

The male gametophyte viability was characterized by two indices - pollen grain germination $(\mathrm{x}, \%)$ and pollen tube elongation $(1, \mu \mathrm{m})$. The method of the hanging drop was used for the pollen grain germination. The pollen was sown in Petri dishes with nutritive medium containing agar, saccharose, $\mathrm{H}_{3} \mathrm{BO}_{3}$ and $\mathrm{CaCl}_{2}$. The percentage of germination and the pollen tube lengths were determined $24 \mathrm{~h}$ after placing the Petri dishes in thermostat at $26^{\circ} \mathrm{C}$. Two or three drops from each flower were used for the pollen germination. Minimum of 100 pollen grains per drop was counted.
The quantitative drought tolerance criteria were calculated according to (19): Tolerance index $(\mathrm{TI})=\mathrm{Yp}-\mathrm{Ys}$; Mean Productivity $(\mathrm{MP})=$ $(\mathrm{Yp}+\mathrm{Ys}) / 2$ and Percent Injury $(\mathrm{I} \%)=(\mathrm{Yp}-$ $\mathrm{Ys}) / \mathrm{Yp} \times 100 . \mathrm{Yp}$ is mean trait performance under control and Ys is mean trait performance under watering regime.

\section{RESULTS AND DISCUSSION}

The investigation of the influence of drought over the male gametophyte of the four pepper genotypes showed the negative effect of that abiotic stress over the pollen fertility and viability in all of the studied plants.

Pollen fertility in dry up genotypes decreases average with from $20.3 \%$ in the mutant lines No.1936 and 1917, to $37.4 \%$ in Albena variety in comparison with the control plants. The increased resistance to water deficit in the male gametophyte of the mutant lines showed during the entire studied period (Figure 1) as lowest fertility values were recorded during the formation and ripening of the first fruits - in September. That corresponded to the work of $(20,21)$, who claim that a critical period for the male gametophyte is the early fruiting.

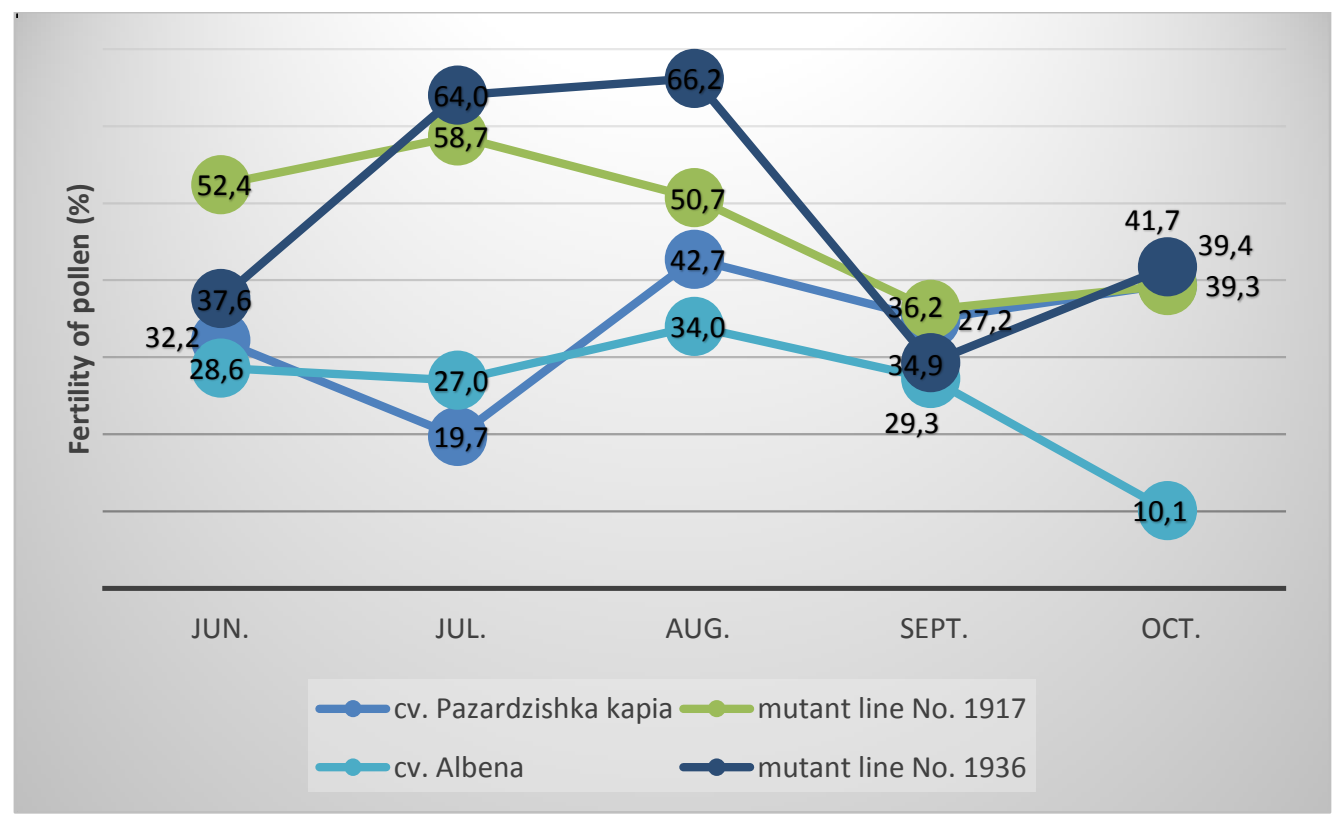

Figure 1. Fertility of pollen (average \%) of genotypes under 50\% water regimes.

The pollen kept its fertility in the normal watering in over than $95.2 \%$ from the reproductive organs of the studied varieties and lines (Figure 2). The water deficit had lethal effect in from $37.7 \%$ to $59.4 \%$ of the investigated buds and flowers in line 1917 and Albena variety as after treating the reproductive organs faded and fall down. 


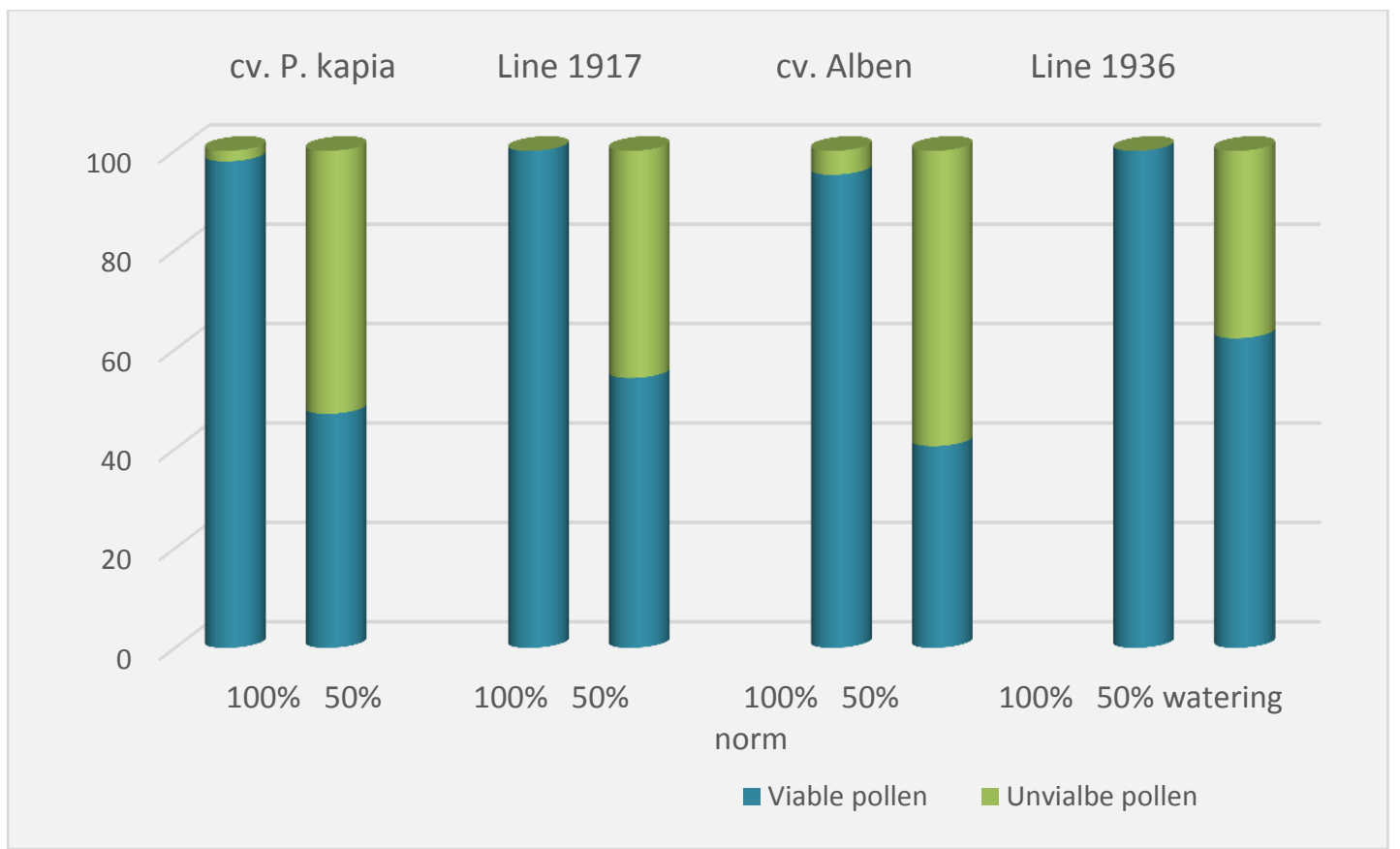

Figure 2. Buds and flowers (\%) with viable and unviable pollen.

Drought had a strong negative effect over the in vitro germination of the pollen grains over the nutrition environment and pollen tube growth. The percentage of the germinated pollen was from 16.6 average in Albena variety to 33.4 in line 1936 (Figure 3). Albena and Pazardzhishka kapia varieties showed the highest pollen sensitivity with lowest restoring potential by that index from the studied genotypes $49.1 \%$ and 51.4 respectively.

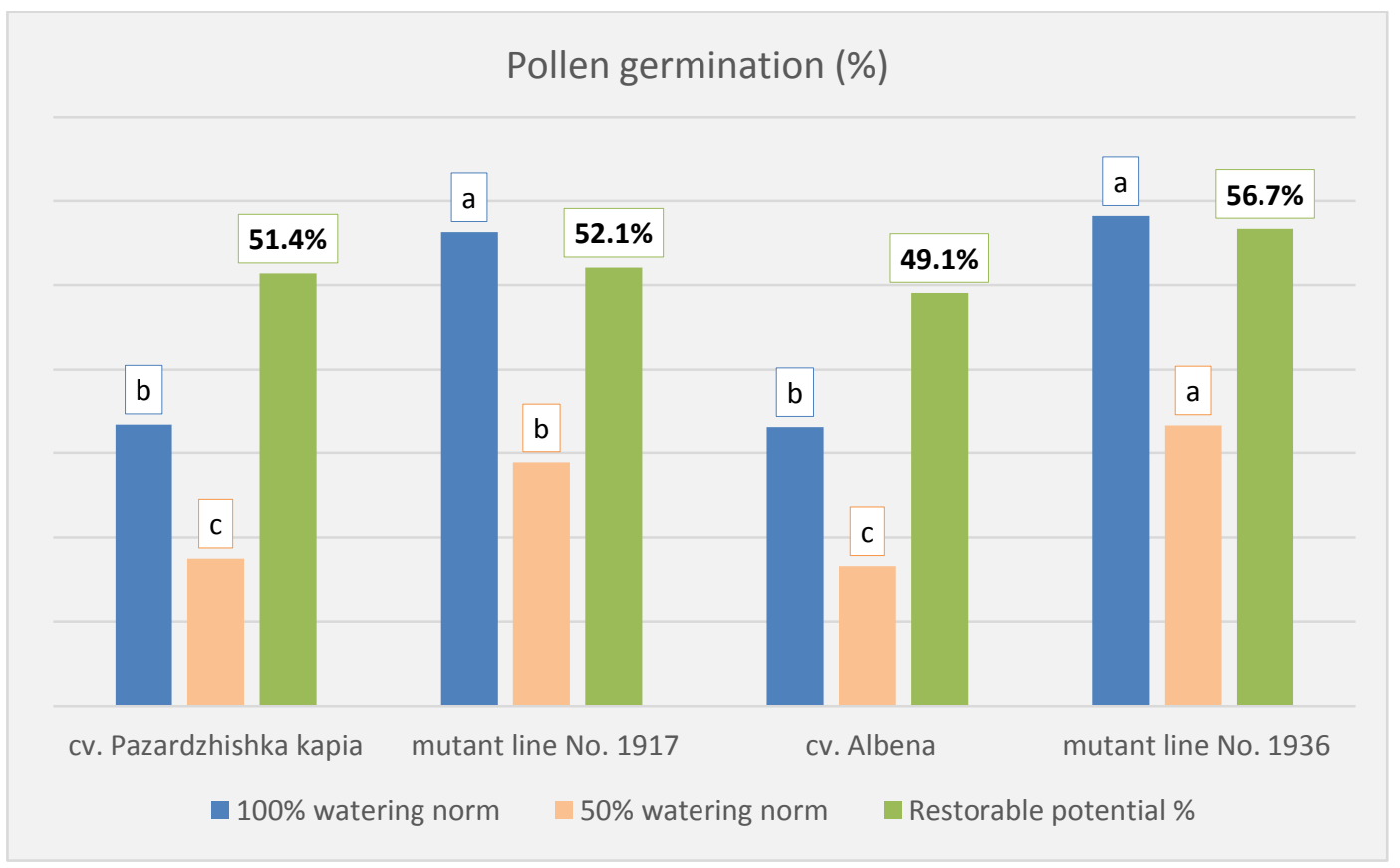

Figure 3. Pollen germination and restorable potential of genotypes under $100 \%$ and $50 \%$ water regimes.

Certain tolerance of the male gametophyte was found in the mutant lines 1917 and 1936, which showed highest indices values defining the pollen viability with mathematically proven difference toward the rest of the genotypes (Figures 3, 4). The pollen germination was $33.4 \%$ average for line 1936 and $28.9 \%$ in line 1917 and the pollen tubes length $-438.7 \mu \mathrm{m}$ and $262.8 \mu \mathrm{m}$ average. The mutant line 1936 stands out with the highest restoring potential $-56.7 \%$ for the pollen germination and $79.5 \%$ in respect of the elongation of the pollen tube. 


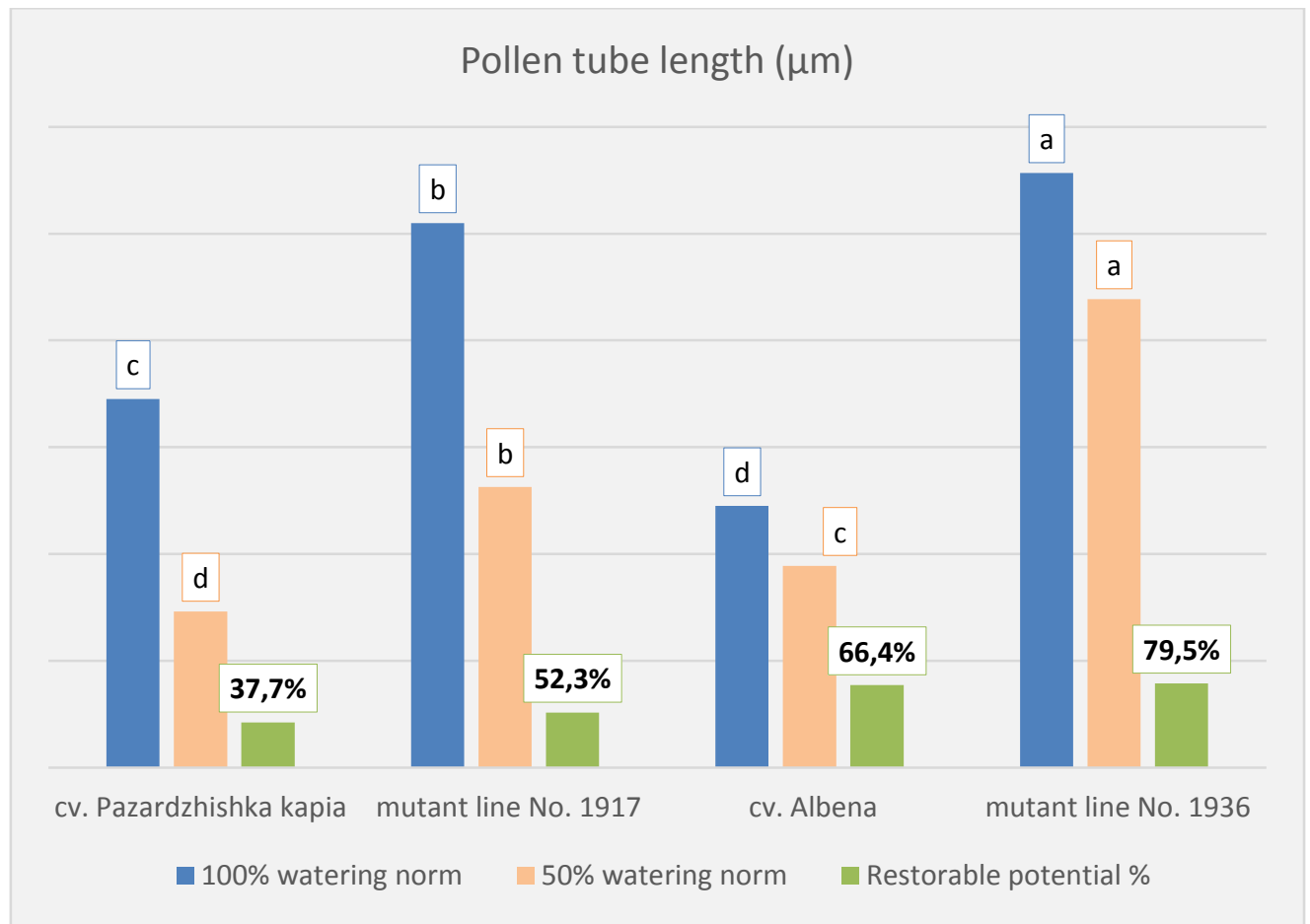

Figure 4. Pollen tubes length and restorable potential of genotypes under $100 \%$ and $50 \%$ water regimes.

The water stress response was obvious when reducing the watering norm with 50\% (Tables 1, 2). Decrease of the total fruit production was with $30.3 \%$ average and decrease of the first quality production with $30.2 \%$ average. That corresponds to the results received by (22) and (23) in which the shortage of water decreases the fruit mass with $34.7 \%$ in comparison with the control watering. The water deficit exert the strongest effect over the productivity of Pazardzhishka kapia variety where the total yield decreased with $46.0 \%$ average and the first quality production with $39.7 \%$ as the quantity of the fruits with small size and sun burn and rotting - 287.2g/plant average (Tables 1, 2). The constant water deficits over pepper significantly increase the fruits that cannot be sold with up to $67 \%$ (24).

Table 1. Fruit yield - productivity (g/plant) and drought tolerance criteria

\begin{tabular}{ccccccc}
\hline & \multicolumn{5}{c}{ Fruit yield / Productivity } \\
\cline { 2 - 7 } Genotypes & $\begin{array}{c}\text { Yp } \\
\text { control }\end{array}$ & $\begin{array}{c}\text { Ys } \\
\text { stress }\end{array}$ & $\begin{array}{c}\text { Potential } \\
\text { (P) }\end{array}$ & $\begin{array}{c}\text { Tolerance } \\
\text { index } \\
\text { (TI) }\end{array}$ & $\begin{array}{c}\text { Mean } \\
\text { productivity } \\
\text { (MP) }\end{array}$ & $\begin{array}{c}\text { Percent } \\
\text { injury } \\
\text { (I\%) }\end{array}$ \\
\hline \multirow{2}{*}{ cv. Pazardzhishka } \\
kapia & 643,7 & 339,7 & 52,8 & 304,0 & 491,7 & 47,2 \\
\hline \multirow{2}{*}{ Mutant line } & 661,6 & 379,9 & 57,4 & 281,7 & 520,8 & 42,6 \\
No. 1917 & 663,9 & 344,0 & 51,8 & 319,9 & 504,0 & 48,2 \\
\hline & 654,4 & 516,0 & 74,3 & 178,5 & 605,2 & 25,7 \\
cv. Albena & 665,6 & 498,2 & 75,9 & 158,0 & 577,2 & 24,1 \\
& 578,9 & 435,3 & 75,2 & 143,6 & 507,1 & 24,8 \\
& 528,5 & 415,4 & 78,6 & 113,2 & 471,9 & 21,4 \\
Mutant line & 515,3 & 455,0 & 88,3 & 60,2 & 485,1 & 11,7 \\
\hline No. 1936 & 713,2 & 507,8 & 71,2 & 205,4 & 610,5 & 28,8 \\
& 744,4 & 521,7 & 70,1 & 222,8 & 633,1 & 29,9 \\
& 708,0 & 503,4 & 71,1 & 204,7 & 605,7 & 28,9 \\
\hline
\end{tabular}


Table 2. Fruit yield - First quality (g/plant) and drought tolerance criteria

\begin{tabular}{|c|c|c|c|c|c|c|}
\hline \multirow[b]{2}{*}{ Genotypes } & \multicolumn{6}{|c|}{ First quality fruit yield } \\
\hline & $\begin{array}{l}\text { Yp } \\
\text { control }\end{array}$ & $\begin{array}{c}\text { Ys } \\
\text { stress }\end{array}$ & $\begin{array}{l}\text { Potential } \\
\text { (P) }\end{array}$ & $\begin{array}{l}\text { Tolerance } \\
\text { index } \\
\text { (TI) }\end{array}$ & $\begin{array}{c}\text { Mean } \\
\text { productivity } \\
(\mathrm{MP})\end{array}$ & $\begin{array}{c}\text { Percent } \\
\text { Injury } \\
\text { (I\%) }\end{array}$ \\
\hline \multirow{3}{*}{$\begin{array}{c}\text { cv. Pazardzhishka } \\
\text { kapia }\end{array}$} & 372,4 & 235,3 & 63,2 & 137,2 & 303,8 & 36,8 \\
\hline & 366,8 & 209,9 & 57,2 & 156,9 & 288,3 & 42,8 \\
\hline & 368,5 & 223,0 & 60,5 & 145,5 & 295,8 & 39,5 \\
\hline \multirow{3}{*}{$\begin{array}{l}\text { Mutant line } \\
\text { No. } 1917\end{array}$} & 404,8 & 300,8 & 74,3 & 104,1 & 352,8 & 25,7 \\
\hline & 439,8 & 282,8 & 64,3 & 157,0 & 361,3 & 35,7 \\
\hline & 407,0 & 295,8 & 72,7 & 111,3 & 351,4 & 27,3 \\
\hline \multirow{3}{*}{ cv. Albena } & 322,6 & 215,2 & 66,7 & 107,4 & 268,9 & 33,3 \\
\hline & 303,1 & 223,2 & 73,6 & 79,9 & 263,1 & 26,4 \\
\hline & 326,7 & 256,6 & 78,5 & 70,1 & 291,6 & 21,5 \\
\hline \multirow{3}{*}{$\begin{array}{l}\text { Mutant line } \\
\text { No. } 1936\end{array}$} & 413,6 & 300,7 & 72,7 & 112,9 & 357,2 & 27,3 \\
\hline & 425,8 & 326,0 & 76,6 & 99,8 & 375,9 & 23,4 \\
\hline & 405,5 & 310,6 & 76,6 & 95,0 & 358,0 & 23,4 \\
\hline
\end{tabular}

For studying the reaction of drought over the pepper plants and selection of genotype with increased tolerance were conducted a number of studies with results in different directions. From a glasshouse study on 'Sonar' sweet pepper (Capsicum annum L.), (25) reported increased fruit dry mass, while (26) observed a $30 \%$ reduction in both fruit fresh and dry masses in the field-grown'Quadratro d'Asti' sweet pepper. Like (27-29) we claim that a selection for drought tolerance only by yield is an unreliable method and complex evaluation is needed when formulating the breeding criteria for tolerance to drought in pepper.

The lower fertility and viability of the pollen in the current study was accompanied by reducing the productivity of the investigated genotypes which gave us a reason to accept the gamete breeding as an effective means for evaluation of pepper for increasing its drought tolerance. As a confirmation of that are the studies of (30-32). They found a connection between the pollen colouring and yield in tomatoes, green beans, and pepper as well as higher pollen fertility in resistant genotypes in comparison with those sensitive to the abiotic stress.

Drought tolerance criteria of the productivity in pepper in conditions of water stress are shown in Tables 1 and 2 . The lowest tolerance index was obtained for the total yield followed by a number of fruits from the first quality in Albena variety. The highest percentage of damage was reported in the total yield $(46 \%$ average) followed by first quality production (39.7\% average) of Pazardzhishka kapia. That confirms that the total productivity was the most affected by the drought and because of that it needs a significant improvement for the drought tolerance. Mean productivity was also higher for the total yield in comparison to the yield from first quality in the studied genotypes with values from $488.1 \%$ in Albena variety to $616.4 \%$ in the mutant line 1936 . We agree with (29) and consider that the three indices for drought tolerance TI, MP and I\% were appropriate in identifying the productivity and could be used in screening and breeding criteria formulating for drought tolerance in pepper.

\section{CONCLUSIONS}

1. Decreasing the watering norm with $50 \%$ simulated the water stress and was effective in investigating the pollen reaction and productivity in pepper plants. That could be used for further improvement of the crop in the field of drought tolerance.

2. Drought influenced negatively over the male gametophyte as it decreases pollen germination and pollen tubes elongation with $21.2 \%$ average and $155.0 \mu \mathrm{m}$ for all of the investigated genotypes.

3. Mutant line No.1936 was defined as a line with increased water deficit tolerance in the treated plants of which were found highest pollen viable indices - germination $33.4 \%$ average and pollen tubes length $438.7 \mu \mathrm{m}$ average and highest productivity - total yield $510.9 \mathrm{~g} /$ plant average and first quality 
production 312.4g/plant. That positive correlation gave us reason to define the gamete breeding as an effective means for increasing pepper drought tolerance.

\section{ACKNOWLEDGMENTS}

This work was financed by Project №16/3 „Competition for financial support for project of junior researchers and postdocs"

\section{REFERENCES}

1. Ferrara, A., S. Lovelli, T. Di Tommaso, and Perniola M., Flowering, growth and fruit setting in greenhouse bell pepper under water stress. J. Agron. 10:12-19, 2011.

2. Ullah H., H. Subthain, I.H. Khalil, W. U. Khan, U. Jamal and Alam M., Stress selection indices an acceptable tool to screen superior wheat genotypes under irrigated and rain-fed conditions Pak. J. Bot., 46(2): 627-638, 2014.

3. Villa-Castorena M., A.L. Ulery, E.A. Catalán-Valencia, Remmenga M.D., "Salinity and nitrogen rate effects on the growth and yield of Chile pepper plants". Soil Science Society of American Journal, 67:1781-1789, 2003.

4. Alvino A., Centritto M., De Lorenzi. F., Photosynthesis response of sunlit and shade pepper (Capsicum annuum L.) leaves at different positions in the canopy under two water regimes. Australia Journal Plant Physiology, 21:377-391, 1994.

5. Bosland P.W. and Votava E.J., Peppers: vegetable and spice Capsicums. Crop Production Science in Horticulture Series. In: Atherton J., Rees A. (Eds.). CABI Publishing, New York: 204, 2000.

6. Delfine S., Tognetti R., Loreto F., Alvino A., Physiological and growth responses to water stress in field-grown bell pepper (Capsicum annuum L.). Journal of Horticulture Science and Biotechnology, 77: 697-704, 2002.

7. De Pascale S., Ruggiero, C., Barbieri G., Physiological responses of pepper to salinity and drought. Journal of the American Society and Horticultural Science, 128: 48-54, 2003.

8. Rosielle, A.A. and Hamblin J., Theoretical aspects of selection for yield in stress and non-stress environment. Crop Sci., 21: 943946, 1981.

9. Gummuluru, S., S.L.A. Hobbs and Jana S., Genotypic variability in physiological characters and its relationship to drought tolerance in durum wheat. Can. J. Plant Sci., 69: 703-711, 1989.
ARNAOUDOVA Y., et al.

10.Pinter, Jr. P.J., G. Zipoli, R.J. Reginato, R.D. Jackson, S.B. Idso and Hohman J.P., Canopy temperature as an indicator of differential water use and yield performance among wheat cultivars. Agric. Water Mange, 18: 35-48, 1990.

11.Filipetti, A. and Ricciardi L., Faba Bean (Vicia faba L.). In: Genetic Improvement of Vegetable Crops, Kalloo, G. and B.O. Berg (Eds.). Pergamon Press, Oxford, pp: 355385, 1993.

12.Kristin, A.S., R.R. Serna, F.I. Perez, B.C. Enriquez and Gallegos J. A. A., Improving common bean performance under drought stress. Crop Sci., 37: 51-60, 1997.

13.Namuco, O.S. and Otoole, J.C., Reproductive stage water stress and sterility. I. Effect of stress during meiosis. Crop Sci. 26: 317-321, 1986.

14.Manjarrez-Sandoval, P., GonzalesHernandez, V.A., Mendoza- Onofre, L.E. and Engleman, E.M., Drought stress effects on the grain yield and panicle development of sorghum. Canad. J. Plant Sci. 69: 631641, 1989.

15.Dorion, S., blonde, S. and Saini, H.S., Induction of male sterility in wheat by meiotic-stage water deficit is preceded by a decline in invertase activity and changes in carbohydrate metabolism in anthers. Plant Physiol, 1996.

16.Lalonde, S., Beeb, D.U. and Saini, H.S., Early signs of disruption of wheat anther development associated with the indictor of male sterility by meiotic-stage water deficit. Sex. Plant Reprod. 10: 40-48, 1997.

17.Barnabás B., Jäger K. \& Fehér A., The effect of drought and heat stress on reproductive processes in cereals. Plant, Cell \& Environment 31, 11-38., 2008.

18.Renák D., Gibalová A., Šolcová K. and Honys D., A new link between stress response and nucleolar function during pollen development in Arabidopsis mediated by AtREN1 protein. Plant, Cell and Environment 37, 670-683, 2014.

19.Rosielle, A.A. and Hamblin J., Theoretical aspects of selection for yield in stress and non-stress environment. Crop Sci., 21: 943946, 1981.

20.Katerji, M., Mastrorilli, M., Hamdy, A., Effects of water stress at different growth stages on pepper yield. Acta Hort. 335, 165-171, 1993.

21.Dalla Costa L. and Gianquinto G., Water stress and water table depth influence yield, water use efficiency and nitrogen recovery 
in bell pepper: lysimeter studies. Australian Journal of Agricultural Research 53(2) 201 - 210, 2002.

22. Aladenola O. and Madramootoo C., Response of greenhouse-grown bell pepper (Capsicum annuum L.) to variable irrigation. Canadian Journal of Plant Science 94(2) 10.4141/cjps2013-048, 2014.

23.Dorjia K., M.H. Behboudiana, J.A. ZegbeDomi'nguezb., Water relations, growth, yield, and fruit quality of hot pepper under deficit irrigation and partial root zone drying. Scientia Horticulturae 104, 137149, 2005.

24.Fernandez, M.D., Gallardo, M., Bonachwla, S., Orgaz, F., Thompson, R.B., Fereres, F., Water use and production of a greenhouse pepper crop under optimum and limited water supply. Journal of Horticultural Science, 104: 220-247, 2005.

25.Chartzoulakis, K. and Drosos, N., Water requirements of glasshouse-grown pepper under drip irrigation. Acta Hort. 499, 175180, 1997.

26.Delfine, S., Alvino, A., Loreto, F., Centrito, M., Santarelli, G., Effects of water stress on the yield and photosynthesis of field-grown sweet pepper (Capsicum annum L.). Acta Hort. 537, 223-229, 2000.

27.Fernandez, G.C.J., Effective selection criteria for assessing plant stress tolerance.
ARNAOUDOVA Y., et al. Proceedings of the International Symposium on Adaptation of Vegetables and other Food Crops in Temperature and Water Stress, August 13-16, 1992, Shanhua, Taiwan, pp: 257-270, 1992.

28. Ehdaie, L., Selection of drought tolerance in wheat. Abstract proceeding of First Iranian Congress of crop Production and plants breeding. Tehran University, Iran, 1993.

29. Showemimo, F.A., and Olarewaju J. D., Drought tolerance indices in sweet pepper (Capsicum annum L.). Int. J. Plant Breed Genet. 1 (1), 29-33, 2007.

30.Dane, F., A.G. Hunter, and O.L. Chambliss., Fruit set, pollen fertility, and combining ability of selected tomato genotypes under high-temperature field conditions. J. Amer. Soc. Hort. Sci. 116:906-910, 1991.

31.Nakano, H., M. Kobayashi, and Terauchi T., Heat acclimation and de-acclimation for pod setting in heat-tolerant varieties of common bean (Phaseolus vulgaris L.). Jpn. J. Trop. Agr. 44:123-129, 2000.

32.Suzuki K., T. Tsukaguchi and Egawa Y., Decrease of pollen stain ability of green bean at high temperatures and relationship to heat tolerance. J. Amer. Soc. Hort. Sci. 126(5):571-574, 2001. 